\title{
Biogas in India: Potential and Integration into Present Energy Systems
}

\author{
A.K. Rupnar*, Sudhir Jain and N.L. Panwar \\ DREE, CTAE, MPUAT, Udaipur, India \\ *Corresponding author
}

\begin{abstract}
A B S T R A C T
\end{abstract}
\section{Ke y w o r ds \\ Biogas technology, Mitigation, Climate change, Greenhouse gas, Anaerobic digestion}

Article Info

Accepted:

17 June 2018

Available Online:

10 July 2018

\begin{abstract}
Biogas is a carbon neutral, sustainable and renewable source of energy that can be produced and consumed without any adverse effect on the environment. Biogas has the potential to cater to the needs for cooking, basic fuel, electricity and can be upgraded to biomethane which then used as transportation fuel as well. The utilization of biogas as a fuel for thermal and engine applications and spent slurry as an organic fertilizer instead of chemical fertilizers contributes in reduction of greenhouse gas emission in both energy and agriculture sector. Biogas is a $\mathrm{CO}_{2}$ neutral fuel and the increase of biogas utilization will help to achieve reduction in greenhouse gas emission. It has the potential in the context of sustainable development that it addresses the social-economic and environmental problems.
\end{abstract}

\section{Introduction}

Changing global climate is the greatest challenge of $21^{\text {st }}$ century. Climate change has become a serious issue as the earth's atmosphere changing gradually with ever increasing rate. The anthropogenic activities are main reason which accelerating the adverse change in natural environment. It was reported that 95 percent probability that human activities are the dominant cause which warmed the planet earth over the past 50 years [20]. The emission from burning of fossil fuels like coal and oil are the prime sources which increased the concentration of greenhouse gases viz. $\mathrm{CO}_{2}, \mathrm{CO}, \mathrm{CH}_{4}, \mathrm{CFC}$ etc. The amount of heat trapped in atmosphere depends on gaseous composition of atmosphere and spectral properties of gases. Anthropogenic activities especially in industrial and transport sector have resulted in enhanced emission of four major GHGs viz. $\mathrm{CO}_{2}, \mathrm{CH}_{4}, \mathrm{~N}_{2} \mathrm{O}$ and $\mathrm{O}_{3}$ which causes more and more heat trap in atmosphere as a result in global warming. The concentration of atmospheric $\mathrm{CO}_{2}$ has increased due to use of fossil fuel in power generation, transportation, deforestation and accelerated process of decomposition of organic matter. The $\mathrm{CH}_{4}$ has increased because of natural gas distribution, agricultural activities and landfills. The increase in $\mathrm{N}_{2} \mathrm{O}$ is a result of agricultural soil management and $\mathrm{N}$ fertilizer use, livestock 
waste management, mobile and stationary fossil fuel, combustion and industrial processes. Though the intensity of consequences of changing natural atmosphere are difficult to predict but the effect of changing natural environment can be recognized that the earth has becoming warmer [20].

Biogas is a sustainable, renewable and environment friendly source of energy that can be produced and consumed without degrading the environment. Utilization of biogas for thermal and engine applications and spent slurry as an organic fertilizer instead of chemical fertilizers contributes in reduction of greenhouse gas emission on both energy and agriculture sector [5].It has health, agricultural, economic and environmental benefit through reduced deforestation and greenhouse gas (GHG) emission which offers more carbon trading that increase the adaptive capacity against present global issue of climate change and its mitigation. Utilization of biomass-based energy resources through appropriate technological interventions has become very important for environmental conservation and sustainable development [35]. Biogas energy technology is considered as economically and technically feasible in among poor people of rural areas[31].

\section{Biogas production potential in India}

Biogas production is the process of an anaerobic digestion of organic substance in the presence of bacteria that of essentially methanogens. In India, it has been estimated that the total potential of biogas production from different organic wastes is about $40,734 \mathrm{Mm}^{3} /$ year [40]. The country has potential of installation of about 12 million household type biogas plants. About 4.75 million of biogas plants have already been installed to the year 2014, which is about $40 \%$ of total potential [30]. It is estimated that India can produce power of about $17000 \mathrm{MW}$ using biogas which is about $10 \%$ of country's energy requirement [10]. Biogas production technology also helps to solve the waste management problem as it disposes different organic wastes in an environment friendly manner. In India, at present most popular and technically mature biogas plants are mostly for the digestion of animal waste. But as the technology advances new feeds tocks viz. kitchen waste, municipal solid waste, agricultural waste, processing industries waste etc. has been successfully being used for biogas generation.

\section{Animal waste}

India is the country with world's largest livestock population about 512.1 million [32]. This comprises different bovine animals like cattle, buffalo and other livestock species like sheep, goat, poultry etc. The total bovine population is about 299.9 million followed by goat and sheep about 200.3 million [32] and out of these, cattle only accounts more than two-third while buffalo accounts for about 28 $\%$ [42]. The organic waste generated by these livestock animals is a best suitable feedstock for biogas production. Among all the livestock waste, the bovine waste that to cattle and buffalo dung is mostly used as it is abundantly and easily available in rural India. The annual average dung yield from cattle is about $4.5 \mathrm{Kg}$ day and that of buffalo is about $10.2 \mathrm{Kg}^{-}$day $^{-}$ (fresh weight), hence the total dung production is estimated to be $718.24 \mathrm{MT}$ which can generate biogas about 15083 $\mathrm{Mm}^{3}$ annually. This biogas provides alternate energy source for different operations like household cooking, thermal application in processing industries, gaseous fuel in automobiles and electricity production

\section{MSW}

Municipal solid waste generation has become a global issue as it is adversely affecting the environment as well as public health all over 
the world and it is more serious in developing countries because of rapid urbanization and population growth. In India about 1,27,486 tons per day of MSW is being generated because of various household, industrial and commercial activities [8]. This MSW contains different compositions of both organic and non-organic waste materials. The organic waste in MSW is a potential feedstock for anaerobic digestion in biogas production process [19]. On an average the organic matter content of MSW in India is about $42.19 \%$ which shows a very good amount for anaerobic digestion. Also the carbon to nitrogen ratio $(\mathrm{C}: \mathrm{N})$ is varies from 21:30 which a most suitable for biomethanation [40]. The biogas production potential from MSW has been estimated about $9.29 \mathrm{Mm}^{3} /$ day at the rate of $95 \mathrm{~m}^{3} / \mathrm{t}$ [45].

\section{Crop residue}

Agriculture is the prime source of biomass in India which generates large quantities of crop residues as a waste. Crop residues represent a large unexploited energy potential that could be harnessed by the production of methane $\left(\mathrm{CH}_{4}\right)$-rich biogas through anaerobic digestion (AD). At present the country produces 686 MT of crop residues per annum, of which 234MT (34\%) is a surplus [15]. The various cellulolytic crop residues like straws from wheat, rice and sorghum, maize stalk can be a good feedstock for anaerobic digestion with a suitable pretreatment. It has been estimated that, India's potential of biogas production from crop residue and agricultural waste is about $45.8 \mathrm{Mm}^{3} /$ day [40].

\section{Biogas production and upgradation}

Biogas production process is an anaerobic process in which the substrate or organic waste is decomposed by micro-organisms in absence of air and biogas is produced which mainly consists of methane and carbon dioxide. The methane gas is combustible gas and used as fuel. The principle biogas production process is mainly a methane fermentation process and involves four major steps viz. Hydrolysis, Acidogenesis, Acidogenesis and Methanogenesis. The biogas produced through these steps is further upgraded for methane enrichment as it can be then used as commercial gaseous fuel in automobiles (Fig. 1).

\section{Hydrolysis}

In this very first step, long chains of the complex carbohydrates, proteins and lipids are broken into shorter ones as sugars, amino acids and fatty acids respectively. Hydrolysis is relatively slow step and it can limit the rate of overall anaerobic digestion process.

$\mathrm{C}_{6} \mathrm{H}_{10} \mathrm{O}_{4}+2 \mathrm{H}_{2} \mathrm{O} \rightarrow \mathrm{C}_{6} \mathrm{H}_{12} \mathrm{O}_{6}+\mathrm{H}_{2}[4]$

\section{Acidogenesis}

In this step, the products of hydrolysis used as substrate and further converted into higher organic acids such propionic acid butyric acid to acetic acid by acidogenic bacteria.

$$
\begin{aligned}
& \mathrm{C}_{6} \mathrm{H}_{12} \mathrm{O}_{6} \rightarrow 2 \mathrm{CH}_{3} \mathrm{CH}_{2} \mathrm{OH}+2 \mathrm{CO}_{2} \\
& \mathrm{C}_{6} \mathrm{H}_{12} \mathrm{O}_{6}+2 \mathrm{H}_{2} \leftrightarrow 2 \mathrm{CH}_{3} \mathrm{CH}_{2} \mathrm{COOH}+2 \mathrm{H}_{2} \mathrm{O}[4] \\
& \mathrm{C}_{6} \mathrm{H}_{12} \mathrm{O}_{6} \rightarrow 3 \mathrm{CH}_{3} \mathrm{COOH}
\end{aligned}
$$

\section{Acetogenesis}

The acetogenic bacteria convert the higher organic acids into subsequent acetic acid and hydrogen gas.

$\mathrm{CH}_{3} \mathrm{CH}_{2} \mathrm{COO}^{-}+3 \mathrm{H}_{2} \mathrm{O} \leftrightarrow \mathrm{CH}_{3} \mathrm{COO}^{-}+\mathrm{H}^{+}+$ $\mathrm{HCO}_{3}{ }^{-}+3 \mathrm{H}_{2}$

$\mathrm{C}_{6} \mathrm{H}_{12} \mathrm{O}_{6}+2 \mathrm{H}_{2} \mathrm{O} \leftrightarrow 2 \mathrm{CH}_{3} \mathrm{COOH}+2 \mathrm{CO}_{2}+$ $4 \mathrm{H}_{2}$ [4] 
$\mathrm{CH}_{3} \mathrm{CH}_{2} \mathrm{OH}+2 \mathrm{H}_{2} \mathrm{O} \leftrightarrow \mathrm{CH}_{3} \mathrm{COO}^{-}+3 \mathrm{H}_{2}+\mathrm{H}^{+}$

\section{Methanogenesis}

In this final step methane is formed by methanogenic bacteria metabolize acid, alcohols, carbon monoxide, carbon dioxide and hydrogen into Methane. The methanogenic bacteria are sensitive to the environment as they only work in a strict anaerobic condition.

$\left.\begin{array}{l}\mathrm{CH}_{3} \mathrm{COOH} \rightarrow \mathrm{CH}_{4}+\mathrm{CO}_{2} \\ \mathrm{CO}_{2}+4 \mathrm{H}_{2} \rightarrow \mathrm{CH}_{4}+2 \mathrm{H}_{2} \mathrm{O}[4]\end{array}\right\}$

$2 \mathrm{CH}_{3} \mathrm{CH}_{2} \mathrm{OH}+\mathrm{CO}_{2} \rightarrow \mathrm{CH}_{4}+2 \mathrm{CH}_{3} \mathrm{COOH}$

\section{Biogas upgradation}

The gas produced from waste consists of 55$65 \%$ methane, $35-45 \%$ carbon dioxide, $0.5-1 \%$ hydrogen sulfide and traces of water vapor. Raw biogas can be directly used to generate power and electricity either by engine application or biogas burner for vehicular use and domestic cooking. But the impurities $\mathrm{CO}_{2}$, $\mathrm{H}_{2} \mathrm{~S}$ and water vapour reduces power output from gas, adds compression cost for bottling and transportation. Biogas, if used for engine application $\mathrm{H}_{2} \mathrm{~S}$ must be removed because it corrodes vital mechanical components which can lead to engine failure. Removal of $\mathrm{CO}_{2}$ gas enriches methane content in biogas. Purified, methane rich biogas gives higher power output and efficiency compared to raw biogas. By removing $\mathrm{H}_{2} \mathrm{~S}$ and water vapour, corrosion problem can be avoided. Bottling of compressed biogas reduces space requirement for storage and concentrates energy content. The process of methane enrichment, removal of impurities, and bottling facilitate easy storage and transportation of purified biogas which then used as fuel for vehicles, cooking and electricity generation. There are different processes used to purify and upgrade raw biogas namely water scrubbing, pressure swing absorption, membrane separation and cryogenic separation[48].

Raw biogas can be purified with different techniques which enrich methane content more than $90 \%$. Bottling of purified biogas into cylinders makes it easily usable for vehicular fuel in addition to meeting stationary $\&$ motive power, electricity generation, thermal application etc. needs in a decentralized manner. Purified biogas can be stored in cylindrical bottles after liquefaction. Biogas like commercially available LPG can't be liquefied under normal temperature and pressure. However, methane can be filled in cylinders at different temperatures and pressures. A critical temperature required for liquefaction of methane is $-82.1^{\circ} \mathrm{C}$ at 4.71 MPa pressure. Most commonly used biogas storage options are in propane or butane tanks and commercial gas cylinders up to 200bar[48].

\section{Integration of biogas into present and future energy systems}

Biogas is mainly a mixture of methane $\left(\mathrm{CH}_{4}\right)$ and carbon dioxide $\left(\mathrm{CO}_{2}\right)$ in which methane is combustible gas used as fuel. Biogas utilization is mainly for cooking, lighting as well as for electricity, heat and power generation and fuel for running small I.C. engines.

\section{Electric power systems}

Presently there are various technologies are available to generate electricity from biogas on household and industrial level. In principle, the chemical energy of the methane gas is converted into mechanical energy in a controlled combustion system by heat engine. This mechanical energy used to activate a generator which produces electric power. Normally $1.5 \mathrm{~kW}$ of electricity can be 
generated from $1 \mathrm{~m}^{3}$ of biogas, depending upon the methane content in biogas [18]. A generator utilizes biogas as an operation fuel but before feeding biogas to genset it has to be cleaned through gas scrubber. Basically, there are two types of generators are being used to generate electricity from biogas i.e. one is duel fuel mode and other runs on $100 \%$ biogas. The duel fuel models are basically diesel generators in which biogas is supplied through air mix normally in 80:20 proportion where biogas acts as a primary fuel and diesel is the pilot fuel. While the $100 \%$ biogas generators run only on biogas and there is no need of any other fuel either for starting or for operation. But these generators require some modification for biogas operation and its cost is high with high maintenance as compared to duel fuel mode generators [13].

\section{Transport}

Bio-CNG, an upgraded biogas has fuel quality close to that of natural gas as it is possible to use in vehicles that runs on natural gas fuel. Bio-CNG is a methane enriched gaseous fuel that is compressed and bottled at a pressure of $20-25 \mathrm{MPa}$ containing more than $97 \%$ methane. It is very similar to the regular $\mathrm{CNG}$ in terms of its fuel properties, engine performance, emissions and economy [44]. The comparative performance study of constant speed IC engine using CNG and bioCNG showed similar results in terms of specific gas consumption, brake power output and thermal efficiency [6]. Application of BioCNG for transportation can substantially reduce $\mathrm{GHG}$ in the range of $60-80 \%$ in comparison to gasoline [21]. Biogas can be used in both heavy duty and light duty vehicles. Light duty vehicles can normally run on both on natural gas and bio-CNG without any modifications, whereas heavy duty vehicles need to be modification in fuel injection and air supply system [22].The existing petrol or diesel engine can be run by upgraded biogas by installing an additional CNG conversion kit [23].Public transport vehicles such as buses, auto rickshaws and personal cars driven on conventional fuels like natural gas, gasoline, and diesel can be converted into bio-CNG vehicles by retro fitting with additional gas tank to the normal fuel system [36].

\section{Households cooking}

In India, most of the household energy used for cooking only. It is estimated that domestic cooking in India uses approximately 1104TWh of energy. Biomass-firewood, crop residue or cow dung- is the prime source of energy for domestic cooking as the $87 \%$ of rural households and $26 \%$ of urban households depends on biomass for cooking[47]. As compared to producer gas and coal gas biogas has a higher heating value which implies increased services. As a fuel for cooking, it is very convenient and economical. Based on the calorific value of biogas, a $2 \mathrm{~m}^{3}$ biogashas the fuel equivalent of $740 \mathrm{~kg}$ of animal dung, or $210 \mathrm{~kg}$ of fuelwood, or $26 \mathrm{~kg}$ of LPG (nearly two standard cylinders), or 37 liters of kerosene, or $88 \mathrm{~kg}$ of charcoal. A $25 \mathrm{~kg}$ of fresh dung gives $5 \mathrm{~kg}$ of dry dung which would generate $1 \mathrm{~m}^{3}$ of biogas [38]. Moreover, biogas offer several other benefits as it burns with clean blue color flame that does not emit any soot particles which keeps kitchen environment clean and safe so that the health hazards are avoided and does not have any offensive odour. Also, biogas is more economical in terms of cost and on a life cycle basis, compared to conventional biomass fuels (dung cakes, fuelwood, crop wastes) as well as LPG. But it is only fractionally costlier than kerosene and LPG, however, they have severe supply constraints in the rural areas [38].Biogas technology is more effective in rural areas as it enhances energy supply decentralization which enable people of rural areas meet their energy requirements at the 
time when access to commercial fuels is difficult or not possible for their use.

\section{Industry}

The installation of biogas plants at an industrial complex has increased and become an alternative option to solve the waste management problem. The biogas plant at factory site is an excellent avenue to dispose of waste in a cost-effective manner and simultaneously generate heat and/or electricity. Industries that are related to processing of agricultural and allied products have high potential for using anaerobic digestion include cattle and poultry industry, fruits \& vegetables industry, pulp and paper, sugar, breweries, and leather etc.

\section{Agriculture and forestry}

As compared to fresh manure, digested slurry from $1 \mathrm{~kg}$ of dung can yield up to extra $0.5 \mathrm{~kg}$ Nitrogen [49].Considering economic value of the bio-slurry as manure the investment in process can be gained back in three to four years [9]. It is estimated that the use of bioslurry annually saves $39 \mathrm{~kg}$ of Nitrogen, $19 \mathrm{~kg}$ Phosphorus and $39 \mathrm{~kg}$ Potassium per household [7]. Bioslurry use can solve problems of soil degradation in areas where dung has been used as a burning fuel and implies that less artificial fertilizer has to be bought which bring revenue to the household [25].

In many developing countries, people use biomass as a primary fuel to meet out their energy needs mostly for cooking in the form of fuelwood, dung, and residues. The direct use of these biomass is inefficient and environmentally detrimental [14]. It is estimated that about 2.6 billion people globally, half of the population in developing countries, use biomass- especially fuelwood from forests - as primary fuel[27].The use of biogas instead of fuel wood can potentially reduce the pressure on forests from collection of fuelwood and also promote regeneration of degraded forests. It also helps in carbon sequestration and maintain the local biodiversity that makes possible the sustainable development of ecosystem services in future [1].

\section{Gas grids}

India's natural gas production has decreased at the rate of $4.18 \%$ from 33.657 BCM in 201415 to 32.249 Billion Cubic Meters (BCM) during the year 2015-16 [3]. Renewable biogas or biomethane can be supplied through existing natural gas pipeline that is fully interchangeable with conventional natural gas and thus can be used in natural gas grids. Like conventional natural gas, Bio-CNG in the form of compressed natural gas $(\mathrm{CNG})$ or liquefied natural gas (LNG) can also be used as a transportation fuel. Biogas in its upgraded version form can be used to generate electricity and heat. The higher purity of biogas can be achieved by removing the impurities like water, carbon dioxide, hydrogen sulfide, and other trace elements. The purified Bio-CNG or biomethane has a higher content of methane than raw biogas, which makes it comparable to conventional natural gas and thus a suitable energy source in applications that require pipeline-quality gas[17]. By purifying biogas more than $97 \%$ of methane can be obtained which makes it completely interchangeable with conventional natural gas. It is interchangeable because it presents the same properties as natural gas and it can be transported, distributed and consumed within the existing natural gas grids and equipment without any modification. However, connecting the Bio-CNG production facility to the natural gas grid opens up to a very wide market of potential Bio-CNG users nevertheless, the opportunity to move the RNG anywhere it may be needed enables 
fantastic opportunities to Bio-CNG producers. [18].

\section{Autonomous/ Hybrid systems}

The extensive use of fossil-based fuel for power and industrial sectors has hampered the sustainable development in a developing country like India. The creation of economical autonomous energy saving system is one of the most important areas of energy supply and energy efficiency of any system. The decentralized options in these sectors for energy supply based on biogas-a renewableenergy provide opportunities to improve environmental condition and enhance economic productivity especially in rural India. The introduction of biogas in small autonomous (decentralized) power systems has the great potential to generate cost effective thermal power as well as electricity and simultaneously reduce the GHG emission. [51]. A biogas-wind or biogas -PV hybrid microgrid can fulfill the power supply at a remote area where supply of conventional power/electricity is difficult and economically not feasible. This can also solve the stability problem of renewable energy connecting to the power system. A multi complementary energy micro grid system not only ensures the maximum benefits of the system when connected to the grid, but also ensures the reliability of the power supply when operating independently [26].

\section{Biogas in the context of sustainable development}

Energy is an essential ingredient of socioenvironmental development and economic growth. India's per capita biogas can contribute in environmental sustainability [12]. In a country like India biogas technology has the potential in the context of sustainable development. It can play vital role for reduction of greenhouse gas emission, and forest conservation. The technology addresses the pressing social, environmental, and economic problems. From the social perspective, especially in rural areas the use of biogas can save time of women labour engaged in daily activities like cleaning, washing, cooking and collecting wood sticks for fuel which on the other hand can be utilized for other productive activities. From the economic perspective, the biogas plant spent slurry can be used as substitute for high cost chemical fertilizers improve soil health and increase in agricultural production. From the environmental perspective, the technology can mitigate the problems of indoor air pollution, and also reduce soil pollution due to the use of excessive chemical fertilizers and water pollution due to organic waste disposal. The depletion of natural resources like fuel wood from forests which is a primary energy sources in rural areas can be significantly reduced by using biogas for cooking and lighting. Therefore, biogas technology offers a wide scope in different sectors of India[24].This clean energy option provides improved health and sanitation and reduce indoor air pollution that is smokeless kitchen which are the most importantly and directly associated with children and women's health and environment. Health and environment along with friendly surroundings contribute for better enterprise integration [50].

\section{Mitigation potential}

Comparing with the fossil fuels and other biomass technologies for energy generation, there is no or low emission of air polluting gases during biogas production and storage [2]. The extensive use of firewood for energy generation leads to local deforestation and degrade air quality. The fuel wood accounts for $54 \%$ of deforestation in developing countries[34] and worldwide it is responsible for $17-25 \%$ of allanthropogenic GHG emissions[46] (Table 1). 
Table.1 Replacement values for different fuels by $1 \mathrm{~m}^{3}$ of biogas

\begin{tabular}{|c|l|c|c|}
\hline S. No. & \multicolumn{1}{|c|}{ Fuel } & $\begin{array}{c}\text { Replacement } \\
\text { value }\end{array}$ & $\begin{array}{c}\text { Estimated Equivalent with 15083 Mm3 } \\
\text { of biogas/annum (in millions) }\end{array}$ \\
\hline $\mathbf{1}$ & LPG & $0.45 \mathrm{Kg}$ & $6787.35 \mathrm{Kg}$ \\
\hline $\mathbf{2}$ & Firewood & $3.47 \mathrm{Kg}$ & $52338.01 \mathrm{Kg}$ \\
\hline $\mathbf{3}$ & Cattle dung cake & $12.30 \mathrm{Kg}$ & $185520.9 \mathrm{Kg}$ \\
\hline $\mathbf{4}$ & Charcoal & $1.4 \mathrm{Kg}$ & $21116.2 \mathrm{Kg}$ \\
\hline $\mathbf{5}$ & Diesel & 0.52 liter & 7843.16 liter \\
\hline $\mathbf{6}$ & Electricity & $6.5 \mathrm{KWh}$ & $98039.5 \mathrm{KWh}$ \\
\hline $\mathbf{7}$ & Kerosene & 0.62 liter & 9351.46 liter \\
\hline $\mathbf{8}$ & Gasoline & 0.8 liter & 12066.4 liter \\
\hline
\end{tabular}

(http://vikaspedia.in/energy/energy-production/bio-energy/biogas)

Fig.1 Biogas production process steps

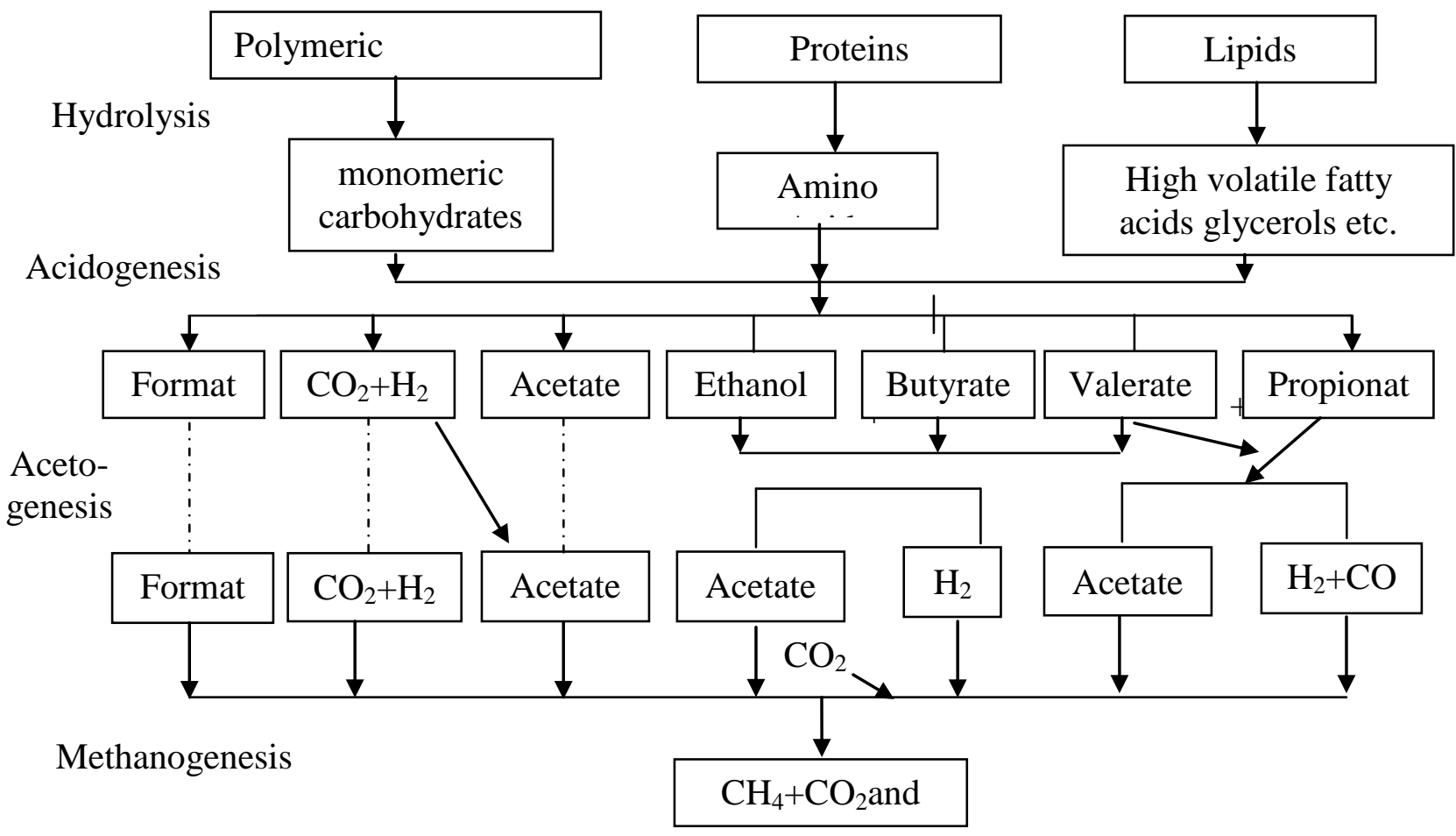


It is estimated that $79 \mathrm{MT}$ of fuelwood can be conserved annually by using biogas technology. Assuming that $40 \%$ of the fuel wood requirements are from the nonsustainable sources and dry wood has $0.5 \mathrm{~T}$ of carbon, the corresponding carbon emissions avoided would be 15.8 MT annually [41]. The animal production sector is responsible for 18 $\%$ of the overall greenhouse gas emissions, measured in $\mathrm{CO}_{2}$ equivalent and for $37 \%$ of anthrophonic methane, which has 23 times the global warming potential of $\mathrm{CO}_{2}$ [39]. Furthermore, $65 \%$ of anthropogenic nitrous oxide and $64 \%$ of anthropogenic ammonia emission originates from the worldwide animal production sector [43]. Animal manure is a major source of anthropogenic greenhouse gas emission (GHG), mostly as methane $\left(\mathrm{CH}_{4}\right)$ and nitrous oxide $\left(\mathrm{N}_{2} \mathrm{O}\right)$. Concerning $\mathrm{CH}_{4}$, livestock manure contributes 5-10\% of total emission [37].

Biogas is considered as $\mathrm{CO}_{2}$ neutral and thus does not add GHG in atmosphere. The utilization of animal manure as a feedstock for biogas production will save plant nutrients and improve health conditions and quality of life in the villages. Biogas is a $\mathrm{CO}_{2}$ neutral fuel and the increase of biogas utilization will achieve $\mathrm{CO}_{2}$ and methane emission decrease [11].However, if biogas is not recovered properly and methane is simply combusted it will contribute to GHGs such that the effect will be 24 times worse than [33].

In conclusion, the production and use of biogas-methane- from organic waste is important for saving in economic terms, keeping the environment clean, and minimizing the effects of climate change by generating cleaner green energy that makes a pollution-free atmosphere and thereby reducing the GHG emission. Biogas technology is reviewed as a promising sustainable solution for agriculture, rural, industrial and automobile sector. The by- product of biogas production, biogas slurry is a potential substitute to the chemical fertilizers. The efforts should be made to maximize the use biogas slurry can help in sustainable crop production system. Biogas also solves major environmental problems such as $\mathrm{CO}_{2}$ emission, soil degradation, deforestation, indoor air pollution, desertification, organic pollution and social problems such as women occupation etc. by replacing wood and other fossil fuels comparing energy content of different fuels. The biogas technology can be possible option to replace petroleum fuels for vehicular, industrial and domestic applications [29].

\section{References}

1. Agarwala, M., Ghoshal, S., Verchot, L., Martius, C., Ahuja, R. and DeFries, R., 2017. Impact of biogas interventions on forest biomass and regeneration in southern India. Global Ecology and Conservation, 11:213-223.

2. Anjum, A., 2012. Biomass: energy and environmental concerns in developing country. Natural gas, 31:8-8.

3. Annual report on Indian Petroleum \& Natural Gas Statistics 2015-16, Ministry of Petroleum and Natural Gas,2016.

4. Bajpai, P., 2017. Basics of anaerobic digestion process. In Anaerobic Technology in Pulp and Paper Industry (7-12). Springer, Singapore.

5. Chand, M., Upadhyay, B.P. and Maskey, R., 2012. Biogas: Option for mitigating and adaptation of climate change. Lap Lambert Academic Publ.

6. Chandra, R., Vijay, V.K., Subbarao, P.M.V. and Khura, T.K., 2011. Performance evaluation of a constant speed IC engine on CNG, methane enriched biogas and biogas. Applied Energy, 88(11):3969-3977.

7. Consult, E., 2004. Biogas users survey of 2003/2004. Alternative Energy Promotion Centre.

8. CPCB India, 2012. Central Pollution 
Control Board, Government of India.

9. Devkota, G.P., 2001. Biogas Technology in Nepal: A sustainable source of energy for rural people. Bindu Devkota.

10. EAI, 2009. Biomethanation in India Biogas potential, trends and prospects posted by Energy Alternatives India.

11. EL-SHIMI, S.A.M.I.R. and ARAFA, S., 1985. Biogas technology transfer to rural communities in Egypt. Power, 96(10):10.

12. Goldemberg, J. Energy, environment and development. Earthscan Publications Ltd, 1996.

13. Gono, M., Kyncl, M., Gono, R. and KŁOSOK-BAZAN, I., 2013. Experience with the production of electricity from biogas at sewage treatment plant in the Czech Republic. PrzeglądElektrotechniczny, 11:12-16.

14. Hall, D.O., 1997. Biomass energy in industrialized countries - a view of the future. Forest ecology and management, 91(1):17-45.

15. Hiloidhari, M., Das, D. and Baruah, D.C., 2014. Bioenergy potential from crop residue biomass in India. Renewable and sustainable energy reviews, 32:504-512.

16. http://wgbis.ces.iisc.ernet.in/energy/paper/ Biogas/intro.htm

17. https://www.afdc.energy.gov/fuels/natural _gas_renewable.html

18. https://www.biogasworld.com/news/rene wable-natural-gas-rng-biomethane

19. Igoni, A.H., Ayotamuno, M.J., Eze, C.L., Ogaji, S.O.T. and Probert, S.D., 2008. Designs of anaerobic digesters for producing biogas from municipal solidwaste. Applied energy, 85(6):430-438.

20. IPCC-AR5, 2014. Climate Change 2014: Mitigation of Climate Change. Intergovernmental Panel on Climate Change.

21. IRENA (2018), Biogas for road vehicles: Technology brief, International Renewable Energy Agency, Abu Dhabi.

22. Jönsson, O. and Persson, M., 2003. Biogas as transportation fuel. Regenerative Kraftstoffe, 37.

23. Kapoor, R., M. and Vijay, V., K., 2009.
Evaluation of existing low-cost gas bottling systems for vehicles use adaption in developing economies. Seventh Framework Programme Theme Energy.

24. Khoiyangbam, R.S., Gupta, N. and Kumar, S., 2011. Biogas Technology: towards sustainable development. The Energy and Resources Institute (TERI).

25. Li, Z., Tang, R., Xia, C., Luo, H. and Zhong, H., 2005. Towards green rural energy in Yunnan, China. Renewable Energy, 30(2):99-108.

26. Liang, H., Yan, L., Yu, L. and Han, J., 2015. Design of micro-grid with biogas power generation.

27. Masera, O.R., Bailis, R., Drigo, R., Ghilardi, A. and Ruiz-Mercado, I., 2015. Environmental burden of traditional bioenergy use. Annual Review of Environment and Resources, 40:121-150.

28. Minde, G., Magdum, S. and Kalyanraman, V., 2013. Biogas as a sustainable alternative for current energy need of India. Journal of Sustainable Energy \& Environment 4:121-132.

29. Minde, G., Magdum, S. and Kalyanraman, V., 2013. Biogas as a sustainable alternative for current energy need of India. Journal of Sustainable Energy \& Environment 4:121-132.

30. MNRE, 2016. Ministry of New and Renewable Energy, Government of India.

31. Moreira, R. J. (2003). Sustainable development evaluation from climate change mitigation options- the case of renewable energy. Prepared for the presessional consultations on the third assessment report of the intergovernmental panel on climate change. Gattamelata, Milan, Italy.

32. NDDB,2017. Livestock Population in India by Species. National Dairy Development Board, India.

33. North Yorkshire Waste Action Group, Objection to Allert on Waste Recovery Park: Climate Change (2011) Available online: http://www.nywag.org/wpcontent/uploads/2012/02/NYWAGClimate-Change.pdf [accessed 28 
February 2014]

34. Osei, W.Y., 1993. Woodfuel and deforestation - answers for a sustainable environment. Journal of Environmental Management, 37(1):51-62.

35. Panthi, J., 2011. Renewable energy technology for reducing greenhouse gas emission and sustainable fuelwood harvesting: A case study of phenapati community forest, Bardia, Nepal (Doctoral dissertation, Tribhuvan University)

36. Papacz, W., 2011. Biogas as vehicle fuel. Journal of KONES, 18:403-410.

37. Polprasert, C., 1989. Organic waste recycling. John Wiley and Sons Ltd..

38. Ramachandra, T.V., 2008. Geographical information system approach for regional biogas potential assessment. Research Journal of Environmental Sciences, 2(3):170-184.

39. Ranade, D.R., Gore, J.A. and Godbole, S.H., 1980. Methanogenic organisms from fermenting slurry of the gobar gas plant. Current Science, 49(10):395-397.

40. Rao, P.V., Baral, S.S., Dey, R. and Mutnuri, S., 2010. Biogas generation potential by anaerobic digestion for sustainable energy development in India. Renewable and Sustainable Energy Reviews, 14(7):2086-2094.

41. Ravindranath, N.H., Rao U. K., Natarajan B., Monga P,. 2000. Renewable energy and environment - a policy analysis for India. Tata McGraw-Hill.

42. Ravindranath, N.H., Somashekar, H.I., Nagaraja, M.S., Sudha, P., Sangeetha, G., Bhattacharya, S.C. and Salam, P.A., 2005. Assessment of sustainable non-plantation biomass resources potential for energy in India. Biomass and Bioenergy, 29(3):178190.

43. Schulz, H., 1986. Biogas-Praxis. Grundlagen, Planung, Anlagenbau,
Beispiele. Staufenbei Freiburg, Ökobuch: 187 str.

44. Shah, M.S., Halder, P.K., Shamsuzzaman, A.S.M., Hossain, M.S., Pal, S.K. and Sarker, E., 2017. Perspectives of Biogas Conversion into Bio-CNG for Automobile Fuel in Bangladesh. Journal of Renewable Energy.

45. Sharholy, M., Ahmad, K., Mahmood, G. and Trivedi, R.C., 2008. Municipal solid waste management in Indian cities-A review. Waste management, 28(2):459467.

46. Strassburg, B., Turner, R.K., Fisher, B., Schaeffer, R. and Lovett, A., 2009. Reducing emissions from deforestationThe "combined incentives" mechanism and empirical simulations. Global Environmental Change, 19(2):265-278.

47. User Guide for India's 2047 Energy Calculator Cooking Sector, Indian Bureau of Energy Efficiency (BEE), 2015

48. Vijay, V.K., Chandra, R., Subbarao, P.M. and Kapdi, S.S., 2006, November. Biogas purification and bottling into $\mathrm{CNG}$ cylinders: producing Bio-CNG from biomass for rural automotive applications. In The 2nd joint international conference on "sustainable energy and environment (SEE 2006):21-23.

49. Werner, U., Stöhr, U. and Hees, N., 1989. Biogas plants in animal husbandry. Deutsches Zentrumfür Entwicklungstechnologien-GATE.

50. Yadav, M.P., 2014. The Role of Biogas for Environmental Sustainability in Nepal: Users perspective. Journal of Indian Research,2(3):49-56.

51. Yang, J. and Chen, B., 2014. Emergy analysis of a biogas-linked agricultural system in rural China-a case study in Gongcheng Yao Autonomous County. Applied Energy, 118:173-182. 
How to cite this article:

Rupnar, A.K., Sudhir Jain and Panwar, N.L. 2018. Biogas in India: Potential and Integration into Present Energy Systems. Int.J.Curr.Microbiol.App.Sci. 7(07): 2175-2186. doi: https://doi.org/10.20546/ijcmas.2018.707.257 